IJHER International Journal of Humanities and Educational Research ISSN: 2757-5403

Volume 4, Issue 1, February 2022

\title{
EDUCATIONAL TREATMENT OF VIOLENCE IN SCHOOLS- PRACTICAL STUDY IN ALGERIAN EDUCATIONAL INSTITUTIONS
}

\section{Sabrina TEBBOUCHE ${ }^{1}$}

Dr, Abdelhamid Mehri Constantine 2 University, Algeria

\begin{abstract}
No doubt that the aggressive (violent) behaviour For a student as a teenager has become a reality that exists in most of our educational institutions.

And this is very interesting for all those who work in the field of education.

In particular, and society in general, departments of educational institutions take a long time and have a negative impact on the educational process. The school departs from the task entrusted to it by society to transform its objectives in accordance with an agreed educational philosophy into behavioural habits that ensure the complete and appropriate development of pupils, as well as the processes of compatibility, adaptation and preparation for the future

Adolescence is a period of time characterized by physical and physiological changes under certain social pressures that make this stage a distinct psychological manifestation, which is reflected in the violent behaviour of certain adolescents who may direct them towards the teacher, their colleagues, or objects around them, and which is the result of the adolescent's much hated feeling for the school of being unable to accept many of his tendencies and interests.
\end{abstract}

Key words: Violence, Educational Treatment, Schools. 


\title{
معالجة تربوية لظاهرة العنف في الوسط المدرسي

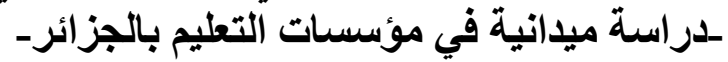

\author{
طبوش صبرينة \\ د، جامعة قسنطينة 2، عبد الحميد مهري، الجزئر ائر
}

مما لا شك فيه أن السلوك العدواني (العنيف) لدى التلميذ في مرحلة المراهقة أصبح حقيقة واقعية موجودة في معظم

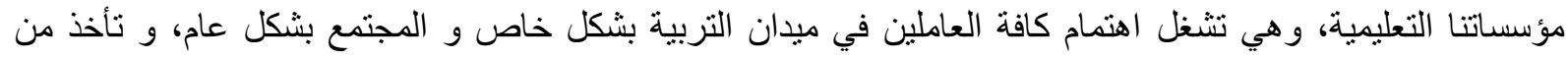

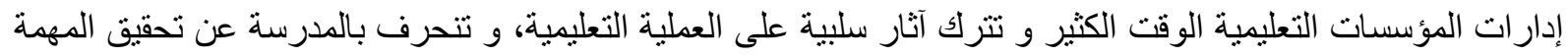

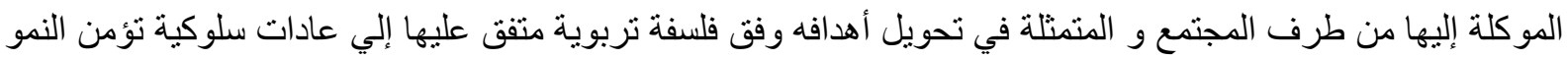

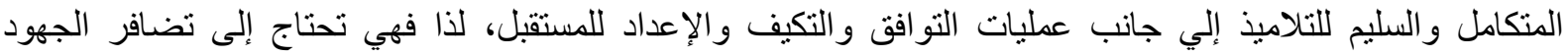

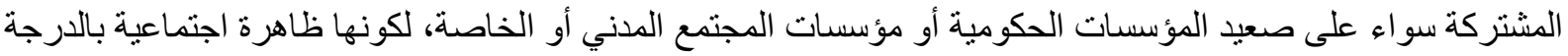

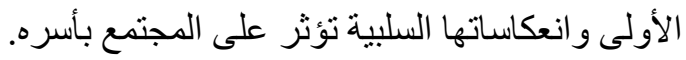

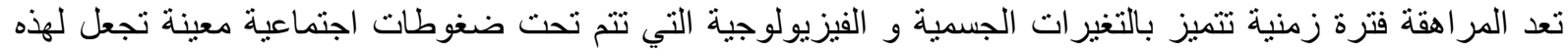

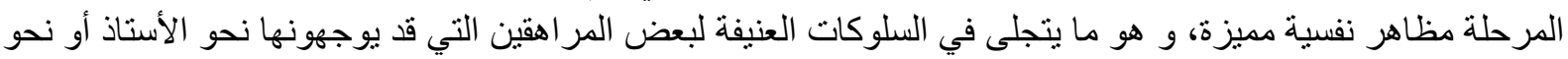

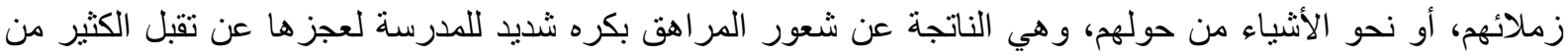

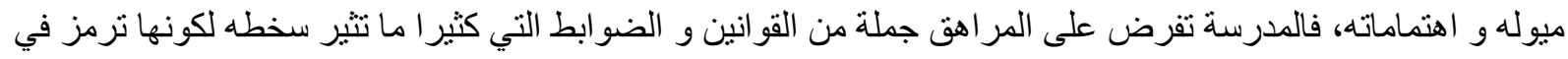

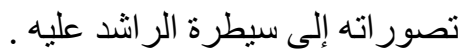

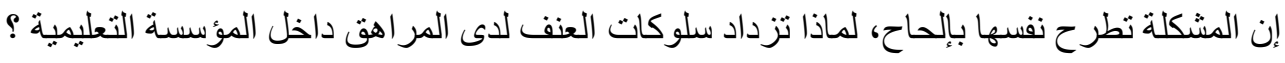

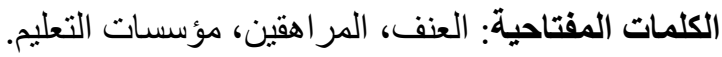

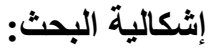

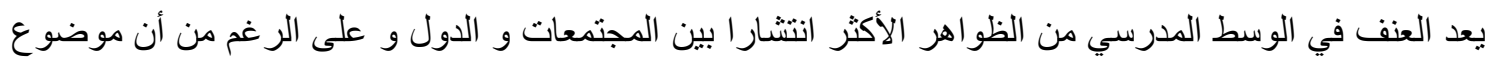

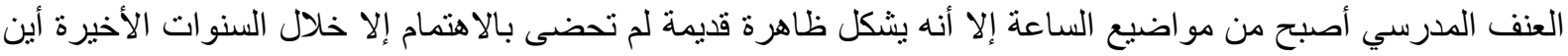

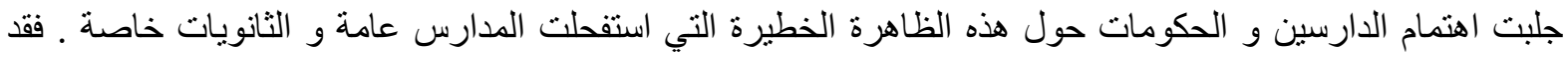

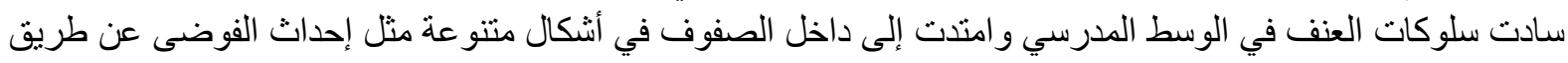
المشاجرة بين التلاميذ، والتحريض على الثغب، العنف اللفظي و الجسدي الموجه ضد التلاميذ والمدرسين، وحتى ضد التي الهيئة الإدارية .

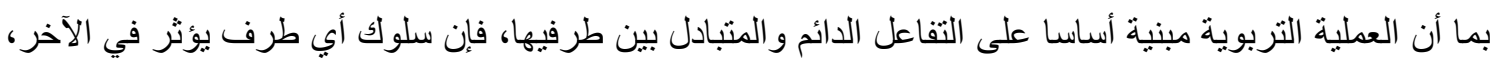

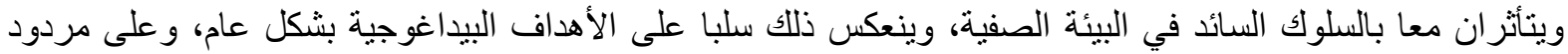

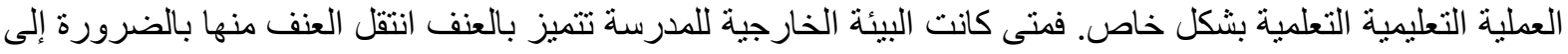
الوسط المدرسي، فكثير ا ما يشتكي المدرسون من صعوبة التحكم في العملية التعليمية وتحقيق الأهداف البيداغوجية في في بيئة صفية يسودها العنف.

إن أهم الانعكاسات التي يفرز ها العنف في الوسط المدرسي على التلاميذ أنفسهم تظهر في صور متعددة منها :عدم التان

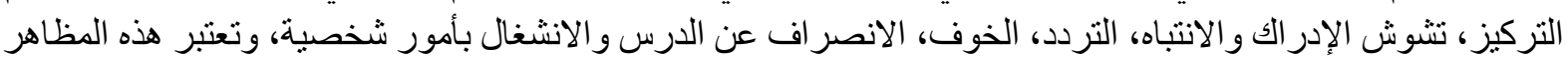

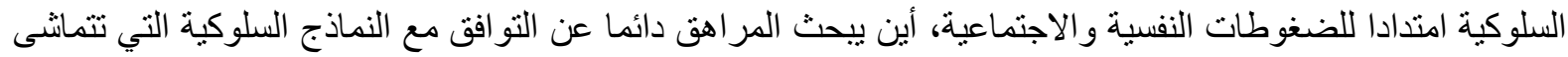

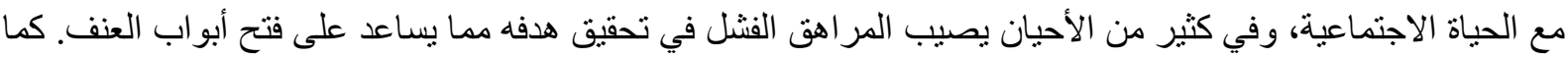

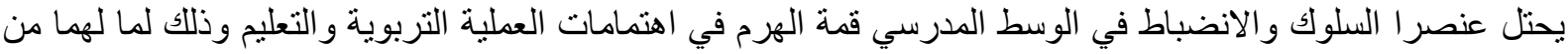

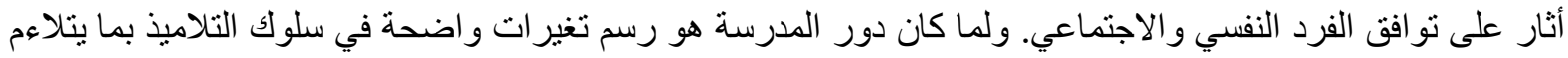

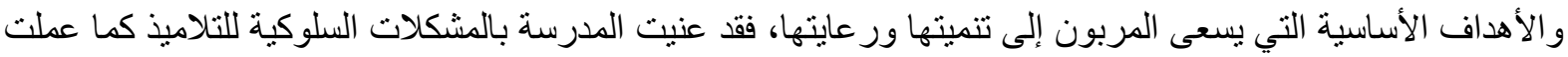
على اكتشاف السلوك غير المقبول الذي يصدر عن بعض التلاميذ والتي تصنفها المدرسة ضمن خانة السلوك الخارج عن 
قانون المدرسة فتعمل على تقويمه باستعمال طرق ووسائل تمكنها من بلوغ المستوى المأمول من الانضباط الصفي فتعمل على رعاية سلوك التلاميذ وتوجيهـ.

من هذا المنظور يتركز نظام المؤسسة التربوية على الانضباط الصفي الذي يمثل عملية قبول التعاليم والتوجيهات

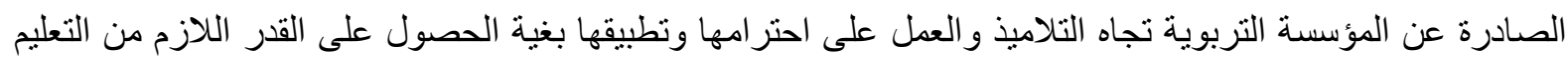

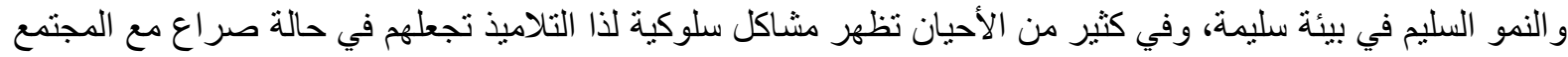

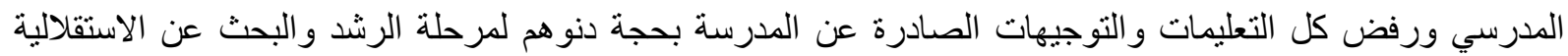

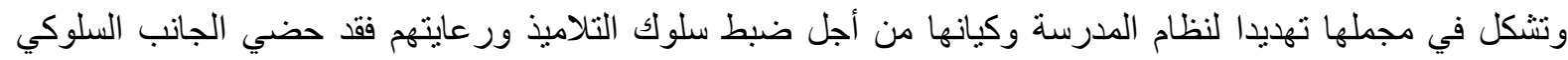

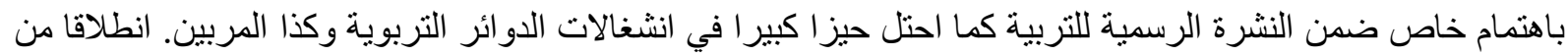

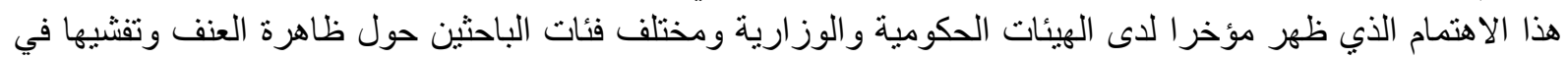
الوسط المدرسي رأينا أننا لابد أن نساهم كباحثين لتقصي حلول ميدانية لهذه الظاهرة، ويكون ذلاهن بطرحنا التساؤل

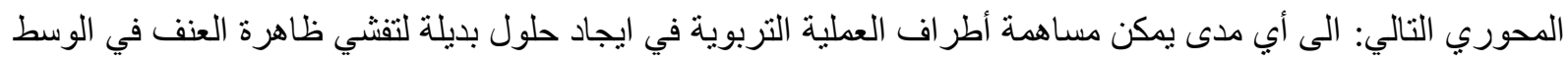

التساؤلات الفرعية:

1. ماهي اقتر احات أطر اف العملية التربوية ( تلمبذ، أستاذ، هيئة إدارية) لإيجاد حل لظاهرة العنف في الوسط الددرسي؟ 2. هل هناك استر اتيجية وقائية لهذه الظاهرة ؟

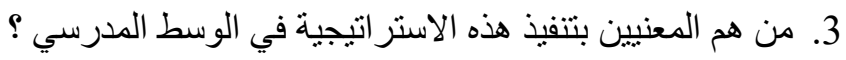

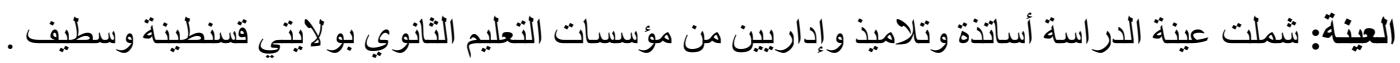

\section{وضعنا لهذه الاراسة أهداف هي:}

1-حصر جميع أثكال و مظاهر العنف الممارس من قبل المراهق داخل المؤسسة التربوية حسب أراء التلاميذو الفريق

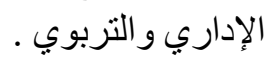

2-التعرف على الأسباب المؤدية إلى ممارسة المر اهق للعنف داخل المؤسسة التربوية . 3-التعرف على طرق معالجة العنف المتخذة من طرف المؤسسات التربوية. 4-اقتر اح أساليب علاجية بديلة حسب أطر اف العملية التربوية.

5-تحديد الإجراءات المتخذة من طرف أعضاء الفريق التربوي والإداري للمؤسسة لتفادي تفشي ظاهرة العنف بالوسط

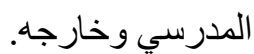

6-جلب اهتمام المختصين إلى ضرورة إيجاد الحلول المناسبة لتفادي انعكاساتها السلبية على المؤسسة التربوية بصفة عامة و التلميذ بصفة خاصة. ولبلوغ هذه الأهداف استعملنا منهجية في العمل تمكننا من ذلك .

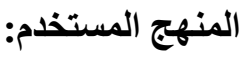
1-طبيعة الموضوع محل الدر اسة تستدعي اللجوء إلى مناهج مثتوعة نلخصها في فئتين:

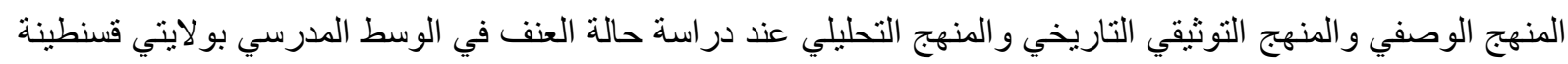

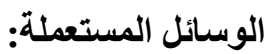

قمنا لدر اسة حالة المؤسسات التربوية بتحليل وثائق عديدة منها:

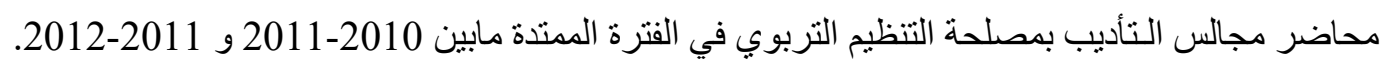
توزيع استمار ات على أعضاء الهيئة الإدارية والتربوية وتلاميذ بعض الثانويات. 


$$
\text { الجانب الميداني }
$$

الاستبيان الخاص بالفريق الإداري ـ مدراء ـ نظار - مر اقبين عامين ـ مساعدين تربويين

بيانات شخصية:

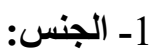

\begin{tabular}{|r|r|r|}
\hline عدد الإداريين المستجوبين & 90 \\
\hline 42 & 48 & 90 \\
\hline
\end{tabular}

المصدر:من إنجاز الباحثة على ضوء نتائج الدراسة الميدانية

قدر عدد المستجوبين من الفريق الإداري ب: 90عضو يختلفون باختلاف الوظيفة و العدد.

2- المهنة:

\begin{tabular}{|c|c|c|c|}
\hline مساعد تزبوي & مراقب عام & ن ناظر & مدير مؤسسة \\
\hline 30 & 20 & 20 & 20 \\
\hline
\end{tabular}

تم استجواب 20 مدير ثانوية و20 ناظر و20 مراقب عام وكذلك 30 مساعد تربوي بسبب احتكاكهم المباثر بالتلامبذ.

3- 3نوات الخبرة في مجال الادارة

\begin{tabular}{|c|c|c|c|c|c|}
\hline 12فمافوق & $12-9$ & $9-6$ & $6-3$ & $3-0$ & سنوات الخبرة \\
\hline 18 & 14 & 28 & 22 & 08 & \\
\hline 20 & 55.15 & 11.31 & 44.24 & 88.8 & d] \\
\hline
\end{tabular}

المصدر:من إنجاز الباحثة على ضوء نتائج الدراسة الميدانية

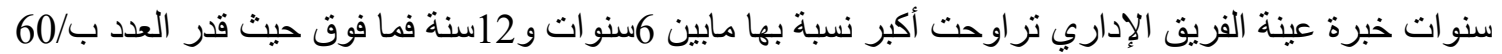

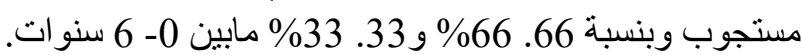


المحور الأول: ما واقع وأثكال العنف في الوسط المدرسي ؟ الجدول الأول: يوضح عدد التقارير المقدمة من طرف الأساتذة والإداريين ضد التناميذ خلال 3 سنوات الأخيرة ؟

\begin{tabular}{|c|c|c|c|}
\hline 2012 & 2011 & 2010 & \\
\hline 816 & 581 & 602 & حدد العدد خلال 3 سنوات الأخيرة \\
\hline
\end{tabular}

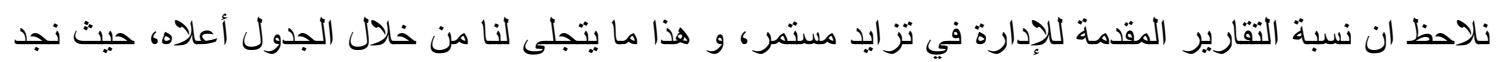

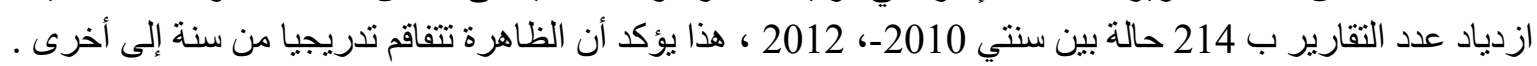
الجدول الثاني: يوضح عدد التقارير التي تم معالجتها داخل المؤسسة من خلال مجلس تأديب داخلي.

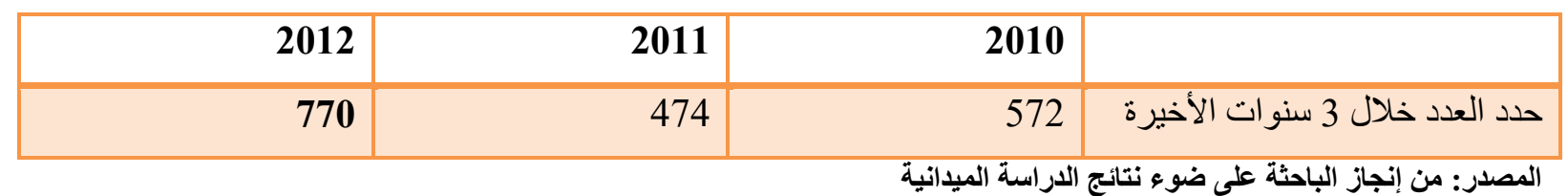

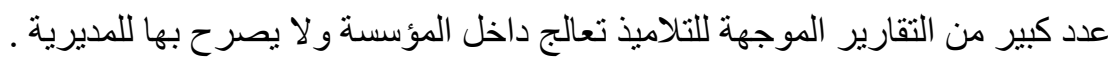

السؤال الثالث: كم هي عدد التقارير التي تم تحويلها الى المجلس الو لائي ة التربية ؟ الجدول الثالث: يوضح عدد التقارير التي تم تحويلها للمجلس الولائي .

\begin{tabular}{|c|c|c|c|c|}
\hline 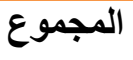 & 2012 & 2011 & 2010 & \\
\hline 135 & 46 & 38 & 33 & حدد العدد خلال 3 سنوات الأخيرة \\
\hline
\end{tabular}

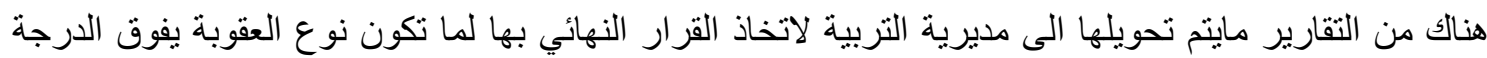

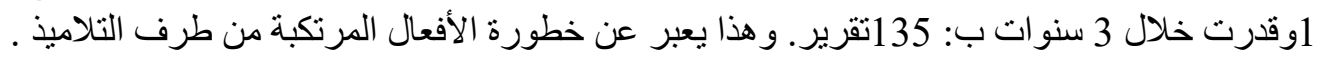

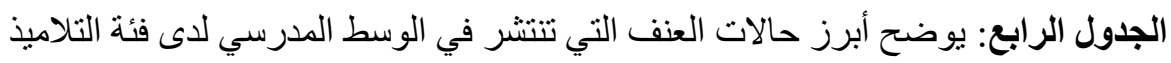

\begin{tabular}{|c|c|c|c|c|c|}
\hline الاجابة & 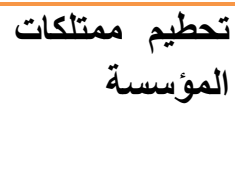 & 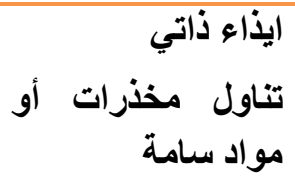 & عنف جسدي & عنف لفظي & 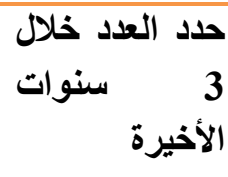 \\
\hline 4 & 22 & 12 & 30 & 66 & \\
\hline
\end{tabular}

المصدر: من إنجاز الباحثة على ضوء نتائج الاراسة الميدانية

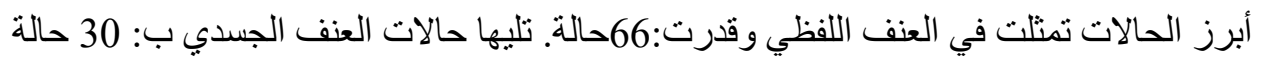
كما أن حالات تحطيم ممنلكات المؤسسة أخذت نسبة معتبرة و هي 22 حالة . 
المحور الثاني: أسباب العنف والحلول البديلة للتخلص من الظاهرة:

الجدول الأول:يوضح أسباب العنف داخل الوسط المدرسي ؟

\begin{tabular}{|c|c|c|c|}
\hline$\%$ & 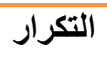 & 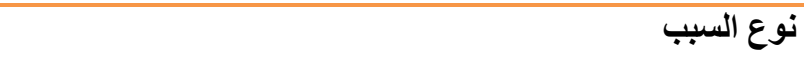 & تصنيف السبب \\
\hline 44.14 & 13 & عدم توفر العدل في معاملة الأبناء & \multirow[t]{10}{*}{ أسباب تعود للأسرة } \\
\hline 66.36 & 33 & الضغوطات التي يعيشها الطفل داخل الأسرة من طرف الأولياء & \\
\hline 50 & 45 & غياب السلطة الأبوية والسماح للتلميذ بالتصرف بكل حرية & \\
\hline 33.13 & 12 & عدم اشباع حاجات التلميذ الأساسية & \\
\hline 44.24 & 22 & المستوى الثقافي للأسرة & \\
\hline 88.48 & 44 & كثرة الخلافات داخل الأسرة & \\
\hline 11.61 & 55 & غياب مر اقبة ومتابعة التلاميذ من طرف الأولياء & \\
\hline 33.13 & 12 & 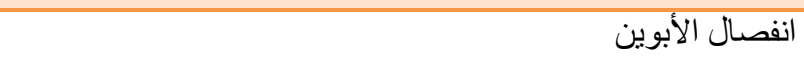 & \\
\hline 66.16 & 15 & تشجيع بعض الأولياء لابنائهم على السلوك العدواني & \\
\hline 22.12 & 11 & شعور التلميذ بكر اهية الأسرة له & \\
\hline 13.33 & 12 & فنثل التلميذ في حياته المدرسية ( التكر ار والرسوب) & \multirow{7}{*}{ وأسباب در اسية } \\
\hline 11.11 & 10 & و السلوك التجانس في تشكيل الأقسام من حيث الفروق الفردية & \\
\hline 36.66 & 33 & عدم تقديم خدمات إرشادية وتحسيسية لحل مشاكل التلاميذ & \\
\hline 77.47 & 43 & وعي التلميذ بالقو انين المانعة لسلوك الضرب & \\
\hline 36. 33 & 33 & كره التلميذ للمادة الدر اسية أو للأستاذ & \\
\hline 33.37 & 34 & ضعف قدرة الأستاذ على التحكم في القسم & \\
\hline 13. 33 & 12 & غياب القو انين الر ادعة لسلوك العنف داخل الوسط المدرسي & \\
\hline 60 & 54 & وجود صر اع نفسي عند المر اهق & \multirow[t]{6}{*}{ أسباب نفسية } \\
\hline 55.25 & 23 & الشعور بالإحباط الاجتماعي في تشكيل علاقات مع الآخرين & \\
\hline 13. 33 & 12 & حب السيطرة و التسلط & \\
\hline 55.25 & 23 & ضعف الوازع الديني لدى الطفل & \\
\hline 10 & 09 & الاحساس بالنقص بين الأقران & \\
\hline 13. 33 & 12 & اهانة الأستاذ للتلميذ مما يجعله يبدي قلق وبالتالي عنف & \\
\hline 44.24 & 22 & تدني مستوى دخل الأسرة & \multirow[t]{3}{*}{ أسباب اقتصنادية } \\
\hline 13. 33 & 12 & ظروف السكن السيئة & \\
\hline 44.24 & 22 & عدم قدرة الأسرة تلبية للتلميذ حاجات ومطالب المدرسة & \\
\hline 25,55 & 23 & تقليد السلوك العدو اني من خلال أفلام العنف & \multirow[t]{4}{*}{ تأثير وسائل الإعلام } \\
\hline 44.44 & 40 & الإنترنيت ودوره تبادل الصور والأفلام المرعبة. & \\
\hline 36.66 & 33 & الحروب والمجازر المروعة والتأثر بالثورات العربية & \\
\hline 22.52 & 47 & ـ الثورة التكنولوجية أنتجت جيلا متمردا لا يخضع لأي منظومة & \\
\hline
\end{tabular}


استخلصنا من الجدول أن الفريق الإداري يرى أن الأسباب الأساسية لظاهرة العنف في الوسط المدرسي تتمثل في

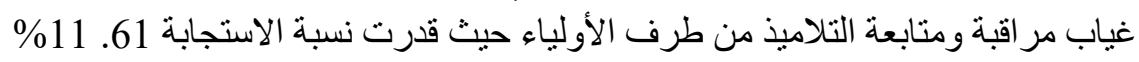

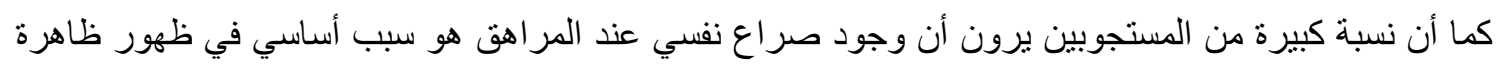

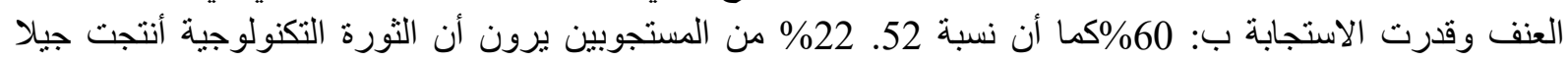

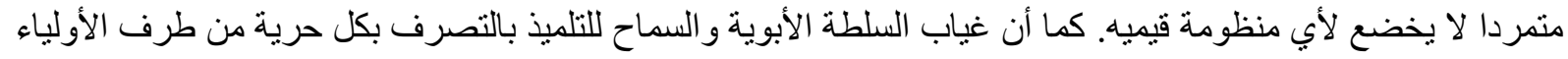

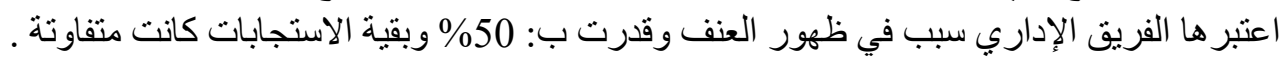

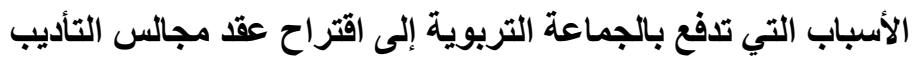

\begin{tabular}{|c|c|c|}
\hline$\%$ & التكرار & أسباب التي دفعت أحد أعضاء الفريق الإداري لاقتراح مجلس التأديب \\
\hline $\begin{array}{l}.38 \\
88\end{array}$ & 35 & ـ استنفاذ جميع وسائل العقاب (إنذار شخصي، كتابي، استدعاء ولي التلميذ \\
\hline 50 & 45 & ـ ـ السلوك غير السوي خاصة السب والكلام الفاحش \\
\hline $\begin{array}{r}.24 \\
44\end{array}$ & 22 & 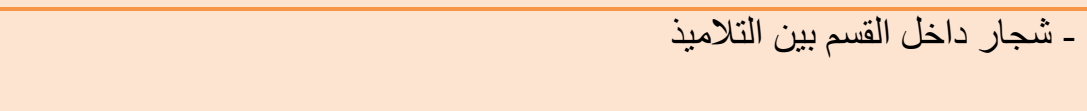 \\
\hline $\begin{array}{r}.36 \\
66\end{array}$ & 33 & ـ التعدي على المساعدين التربويين بالكلام و عدم الامتثال كالنظام الداخلي للمؤسسة \\
\hline $\begin{array}{r}.12 \\
22\end{array}$ & 11 & ـ شعور الأستاذ بالإهانة أمام زملائه يدفعه لإعادة الاعتبار لشخصه بمجلس تأديبي . \\
\hline 10 & 09 & ـ أسباب خارجية مثل المحيط الاجتماعي و الأسري للأستاذ \\
\hline 8. 88 & 08 & ـ أسباب داخلية ( داخل المؤسسة التربوية) \\
\hline 3. 33 & 03 & ـ عقليات الأساتذة القدامى التي لا تتمانشى مع عقلية الجيل الجديد ( صر اع الأجيال) \\
\hline $\begin{array}{r}28 . \\
88\end{array}$ & 26 & 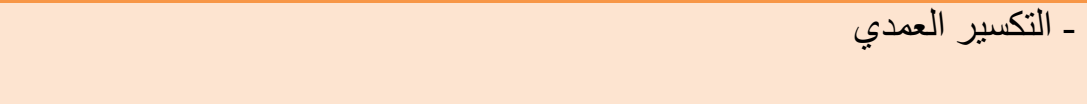 \\
\hline $\begin{array}{r}25 . \\
55\end{array}$ & 23 & ـ الفش في الامتحانات \\
\hline
\end{tabular}

المصدر:من إنجاز الباحثة على ضوء نتائج الدراسة الميدانية

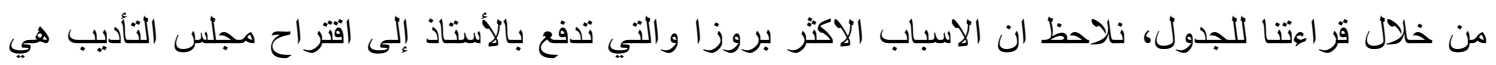

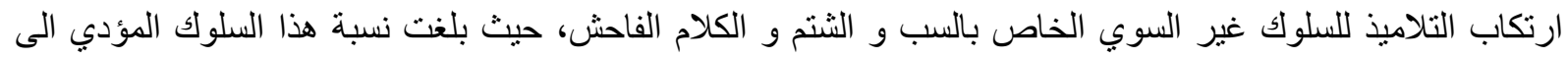

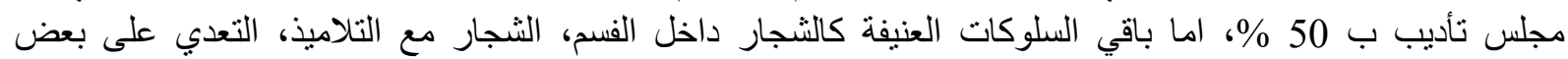

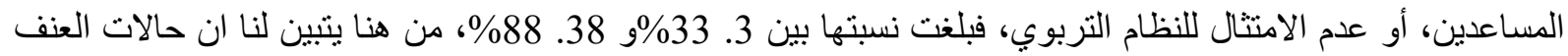

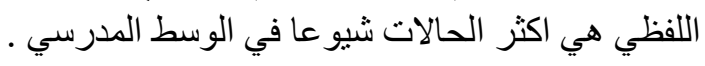
الجدول الثاني: يوضح مدى فعالية مجلس التأديب كحل في معالجة الظاهرة. هل تعتبر مجالس التأديب وسيلة مناسبة لعلاج ظاهرة ظاهرة العنف في الوسط المدرسي؟

\begin{tabular}{|c|c|c|}
\hline النسبة المئوية & عدد التكرارات & \\
\hline$\% 11.61$ & 55 & ن نعم \\
\hline$\% 33.23$ & 21 & ل \\
\hline$\% 55.15$ & 14 & أحيانا \\
\hline
\end{tabular}

المصدر: من إنجاز الباحثة على ضوء نتائج الاراسة الميدانية

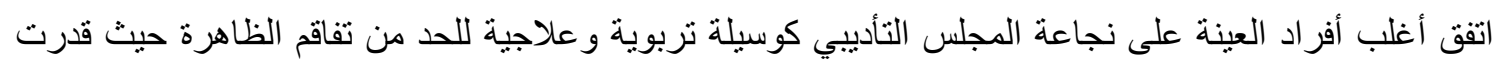

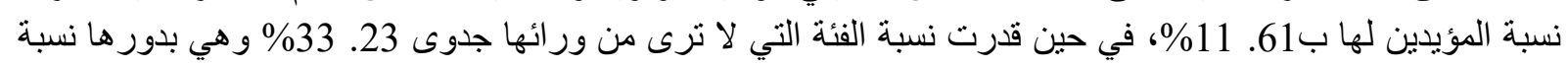


تحتاج الى التمعن فيها، كما ان نسبة 15. 55\% من العينة ترى أن مجالس التأديب قد تكون وسيلة علاجية في بعض

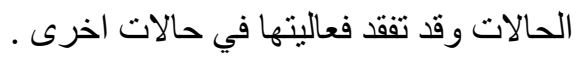
الجدول الثالث: يوضح الإستر اتيجية التي يقترحوها الإداريين كحل لهذه الظاهرة

\begin{tabular}{|c|c|c|}
\hline$\%$ & 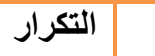 & 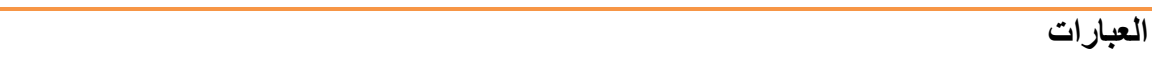 \\
\hline 72.22 & 65 & تحرير تقارير ضد التلاميذ الذين يقومون بمثل هذا السلوك. \\
\hline 85.55 & 77 & احالة التلاميذ على مجالس تأديب . \\
\hline 50 & 45 & احالة التلميذ الذي يظهر هذا السلوك على مختص نفساني. \\
\hline 56.66 & 51 & تنظيم حملات تحسيسية داخل المؤسسات التربوية. \\
\hline 48.88 & 44 & اعادة النظر في القوانين الرادعة لمثل هذه السلوكات في مضمون التشريع المدرسي. \\
\hline 74.44 & 67 & دمج موضوع العنف، أخطاره، أسبابه واستراتيجيات الوقاية ضمن المقررات الدارسية . \\
\hline 96.66 & 87 & توسيع نطاق الاستعاتة بوسائل الاعلام المسمو عة، المرئية، المكتوبة للتخفيف من الظاهرة . \\
\hline 24.44 & 22 & تطبيق تقتيات الوساطة في الوسط المدرسي \\
\hline 48.88 & 44 & أساليب الاتصال مع هذا النوع من التلاميذ النصائ ومستشار التوجيه في مجال دراسة الظواهر الاجتماعية وتحسين \\
\hline 13.33 & 12 & توظيف أنثخاص قادرين على آداء مهامهم في قطاع التربية \\
\hline 37.77 & 34 & اعتماد دورات تدريبية ذات مستوى عالمي لأعضاء الفريق الإداري والتربوي \\
\hline
\end{tabular}

المصدر:من إنجاز الباحثة على ضوء نتائج الاراسة الميدانية

نستخلص من خلال الجدول أن نسبة كبيرة من المستجوبين ترى أن وسائل الاعلام لهل دور فعال في توعية الهائ الأشخاص عامة و المر اهقين خاصة حول أخطار الظاهرة وطرق الوقاية منها حيث قدرت نسبة الاستجابة ب: 66 .96 \%

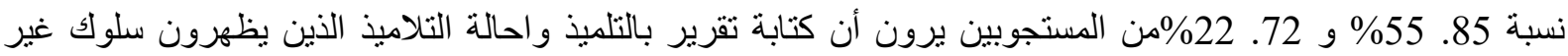

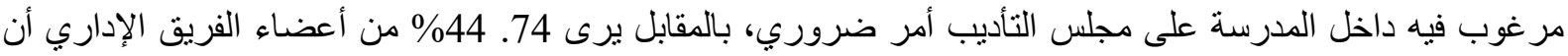

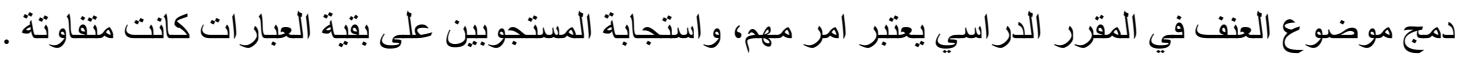
حالات أخرى أذكر ها ماعن

\begin{tabular}{|c|c|c|}
\hline 44.24 & 22 & واجتماعيا واخلاقيا سليما . \\
\hline 44.4 & 04 & تنتزيز المنظومة القيمية للمراهقين من اجل مواجهة التغير ألقيمي وحمايتهم من الصراع الذي يقودهم إلى \\
\hline 11.11 & 10 & العقاب و التوبيخ الضبط و الردع داخل المؤسسات التعليمية بشرط ان تحمل معاني التهذيب و التعديل لا معاني \\
\hline 55.5 & 05 & تكوين افراد الجماعة التربوية وتوعيتهم بأهمية دورهم في تنشئة أجيال متوافقة نفسيا واجتماعيا و علميا . \\
\hline 33.13 & 12 & ضرورة تكامل كل من دور الأسرة و المدرسة في معالجة وتخفيف سلوكات العنف و التمرد لاى المراهق . \\
\hline
\end{tabular}
المصدر:من إنجاز الباحثة على ضوء نتائج الاراسة الميدانية

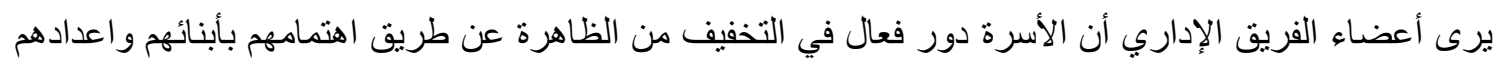
تربويا واجتماعي كما يندد أعضا الفريق الإداري أن من الضروري تكامل كل من دور الأسرة و المدرسة في معالجة وتخفيف سلوكات العنف و التمرد لاى المر اهن. الاستبيان الخاص بالأساتذة 
الجنس:

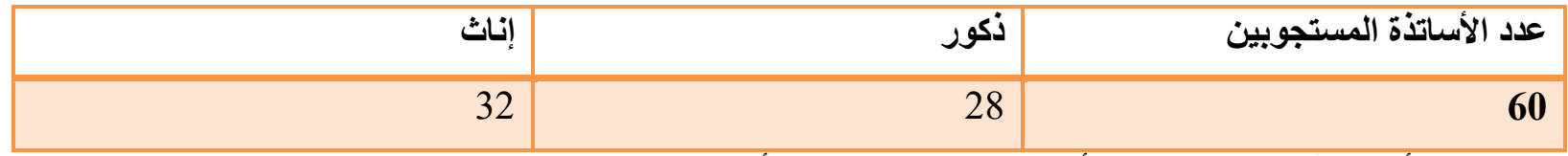

قدر عدد الأساتذة المستجوبين ب:60 أستاذ منهم 28 ذكور و32أنثى

سنوات الخبرة في التدريس

\begin{tabular}{|r|r|r|r|r|r|r|}
\hline $\mathbf{1 2}$ & $\mathbf{1 2 - 1 0}$ & $\mathbf{1 0 - 8}$ & $\mathbf{8 - 6}$ & $\mathbf{6 - 4}$ & $\mathbf{4 - 2}$ & $\mathbf{2}$-0 \\
\hline 05 & 06 & $/ /$ & 04 & 18 & 16 & $\mathbf{1 1}$ \\
\hline 33.08 & 00.10 & $/ /$ & 66.06 & 00.30 & 66.26 & $\mathbf{3 3 . 1 8}$ \\
\hline
\end{tabular}

المصدر:من إنجاز الباحثة على ضوء نتائج الاراسة الميانية

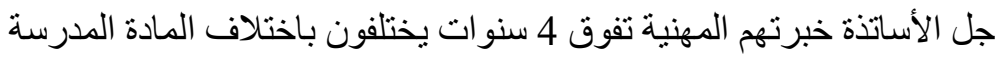

المادة المدرسة:

\begin{tabular}{|c|c|c|c|c|c|c|c|}
\hline ت- بلنية & تاريخ وجغرافيا & علوم & فيزياء & انجليزية & رياضيات & فرنسية & عربية \\
\hline 02 & 07 & 07 & 10 & 08 & 09 & 08 & 09 \\
\hline 33.3 & 66.11 & 66.11 & 66.16 & 33.13 & 00.15 & 33.13 & 00.15 \\
\hline
\end{tabular}

المصدر: من إنجاز الباحثة على ضوء نتائج الاراسة الميدانية

فضلنا أن يكون هناك تتوع في المو اد المدرسة لتقصي مدى تأنثير طبيعة المادة على تفشي الظاهرة و الجدول يوضح عدد الأساتذة المستجوبين في كل مادة ف

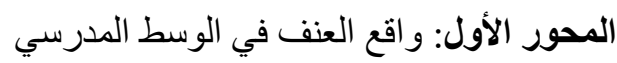
الجدول 01: يوضح عدد الأساتذة الذين سبق لهم أن لاحظو اوجود الوبط حالات من السلوكات العدوانية

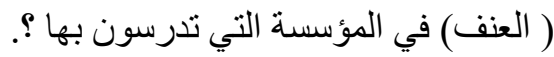

\begin{tabular}{|c|c|c|}
\hline النسبة المئوية & عدد التكرارات & \\
\hline 66.71 & 43 & 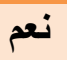 \\
\hline 33.28 & 17 & ע \\
\hline
\end{tabular}

71. 66\% من الأساتذة سبق لهم أن لاحظو سلوكات عنيفة في المؤسسة التي يدرسون بهاو هذا دليل على انتشار الظاهرة بشكل ملفت للانتباه الجدول 02: يوضح عدد هذه الحالات بالتقريب خلال 3 سنوات الأخيرة؛

\begin{tabular}{|c|c|c|c|c|c|c|c|}
\hline تاريخ وجغرافيا & علوم & فيزياء & انجليزية & رياضيات & فرنسية & عربية & المواد \\
\hline 05 & // & 03 & 10 & 18 & 10 & 04 & \\
\hline 8.33 & // & 05.00 & 16.66 & 30.00 & 16.66 & 6. 66 & \\
\hline
\end{tabular}
المصدر:من إنجاز الباحثة على ضوء نتائج الدراسة الميدانية

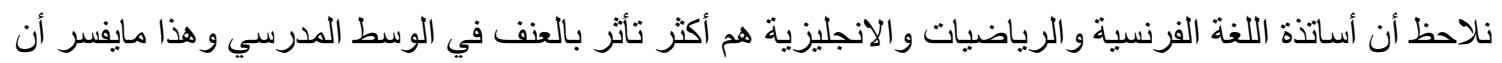

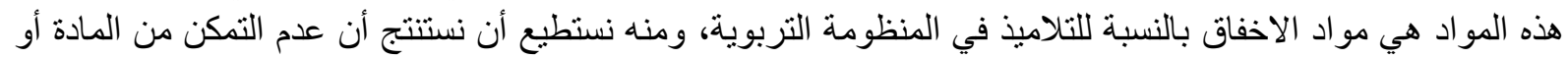

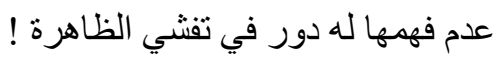


الجدول:03 يوضح الفئة الأكثر عرضة لسلوك العنف داخل المؤسسات حسب الأساتذة ؟

\begin{tabular}{|c|c|c|c|c|}
\hline عمال مهنيين & إداريين & أساتذة & تلاميذ & لالفئة \\
\hline 12 & 18 & 29 & 21 & \\
\hline 20 & 30 & 48.33 & 35.00 & \\
\hline
\end{tabular}

المصدر: من إنجاز الباحثة على ضوء نتائج الاراسة الميدانية

الفئة الأكثر عرضة للعنف حسب الفئة المستجوبة هي فئة الأساتذة والتلاميذ بنسبتين متفاوتنتين قدرتا ب: 33 .48\%

بالنسبة للأساتذة و 35. 00\% بالنسبة للتناميذ.

الجدول: 04 يوضح الفئة الأكثر ممارسة لسلوك العنف في الوسط الوسط المدرسي ؟.

\begin{tabular}{|c|c|c|c|c|c|}
\hline \multicolumn{2}{|r|}{$\gamma$} & & نعم & \multicolumn{2}{|c|}{ الفئة 2 } \\
\hline$\%$ & تكر ارت & $\%$ & تكرارات & & الفئة 1 \\
\hline & & 26.66 & 16 & مع بعضهم البعض & \multirow[t]{4}{*}{ فئة التلاميذ } \\
\hline $\begin{array}{r}28 . \\
33\end{array}$ & 17 & 30.00 & 18 & ضد الأساتذة & \\
\hline 1.66 & 01 & 11.66 & 07 & ضد الإدارة & \\
\hline 5.00 & 03 & 3.33 & 02 & ضد العمال المهنيين & \\
\hline 5.00 & 03 & 3.33 & 02 & مع بعضهم البعض & \multirow[t]{4}{*}{ فئة الأساتذة } \\
\hline 5.00 & 03 & & & ضد التلاميذ & \\
\hline 5.00 & 03 & & & ضد الإدارة & \\
\hline 5.00 & 03 & & & ضد العمال المهنيين & \\
\hline 5.00 & 03 & & & مع بعضهم البعض & \multirow[t]{4}{*}{ فئة العمال المهنيين } \\
\hline 5.00 & 03 & & & ضد التلاميذ & \\
\hline 5.00 & 03 & & & ضد الإدارة & \\
\hline $\begin{array}{r}11 . \\
66\end{array}$ & 07 & 8.33 & 05 & ضد الأساتذة & \\
\hline 25 & 15 & & & مع بعضهم البعض & \multirow[t]{4}{*}{ فئة الإداريين } \\
\hline \multirow[t]{3}{*}{$\begin{array}{r}23 . \\
33\end{array}$} & 14 & 1. 66 & 01 & ضد التلاميذ & \\
\hline & & & & ضد العمال المهنيين & \\
\hline & & & & ضد الأساتذة & \\
\hline
\end{tabular}

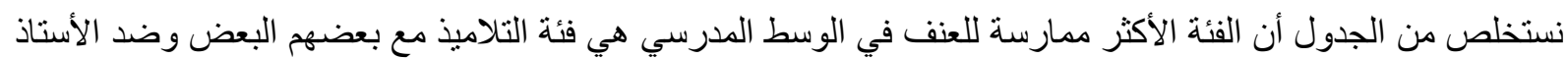

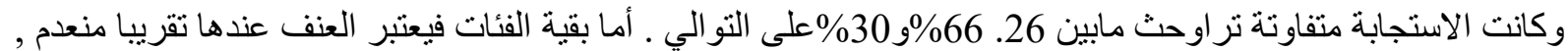
وبالتالي نستطيع أن نستنتج أن العنف في الوسط المدرسي يظهر عند فئة المر اهقين أكثر. 
المحور الثاني: أنواع السلوكات العدوانية الممارسة في الوسط المدرسي وأسباب انتثارها: الجدول الأول: يوضح نو عية السلوكات العدو انية الأكثر انتشار ا في الوسط الددرسي ؟

\begin{tabular}{|c|c|c|c|c|c|}
\hline مختامة & في المؤسسة مثتل عمدات & سرقة من منتأستة & (ضداء جسدي & (عتداء لفظي & نوع السلوك \\
\hline 15 & 27 & 17 & 18 & 28 & النوع \\
\hline 25 & 45 & 33.28 & 00.30 & 66.46 & $\%$ \\
\hline
\end{tabular}

المصدر:من إنجاز الباحثة على ضوء نتائج الاراسة الميدانية

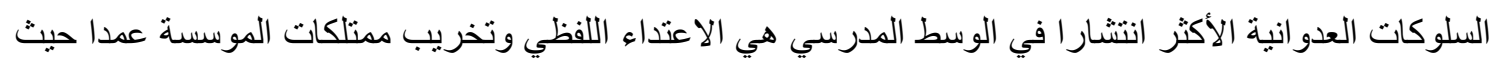
تراوحت النسب مابين: 45. 00 \%و 46. 66\% و وبيقة النسب هي متفاوتة. الجدول الثاني: يوضح الأسباب التي ترونها ور اء انتشار هذه الظاهرة في الوسط المدرسي ؟.

\begin{tabular}{|c|c|c|}
\hline$\%$ & عدد التكرارات & \\
\hline 66.46 & 28 & ـ ـ أسباب نفسية \\
\hline 66.41 & 25 & أسباب اجتماعية \\
\hline 66.26 & 16 & ـ أسباب عاطفية \\
\hline 33.23 & 14 & أسباب تحصيلية \\
\hline 33.43 & 26 & ـ أسباب أخلاقية \\
\hline 66.36 & 22 & ـالغش أثناء الامتحانات \\
\hline 66.46 & 28 & نقص في التحسيس و التو اصل داخل المدرسة \\
\hline 25 & 15 & ـتناول المخدر ات \\
\hline
\end{tabular}

المصدر: من إنجاز الباحثة على ضوء نتائج الاراسة الميدانية

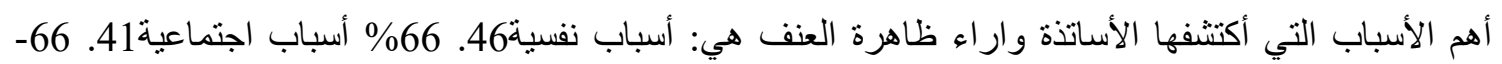

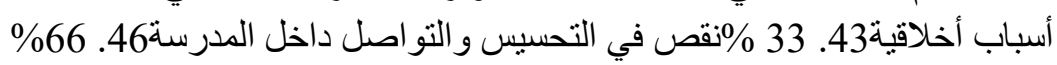


المحور الثالث: الاستراتيجيات الوقائية والعلاجية المقترحة لإيجاد حلول بديلة لظاهرة العنف في الوسط المدرسي

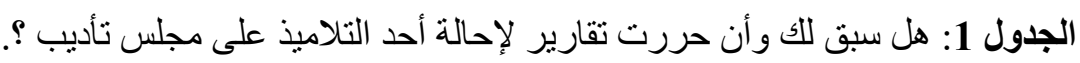

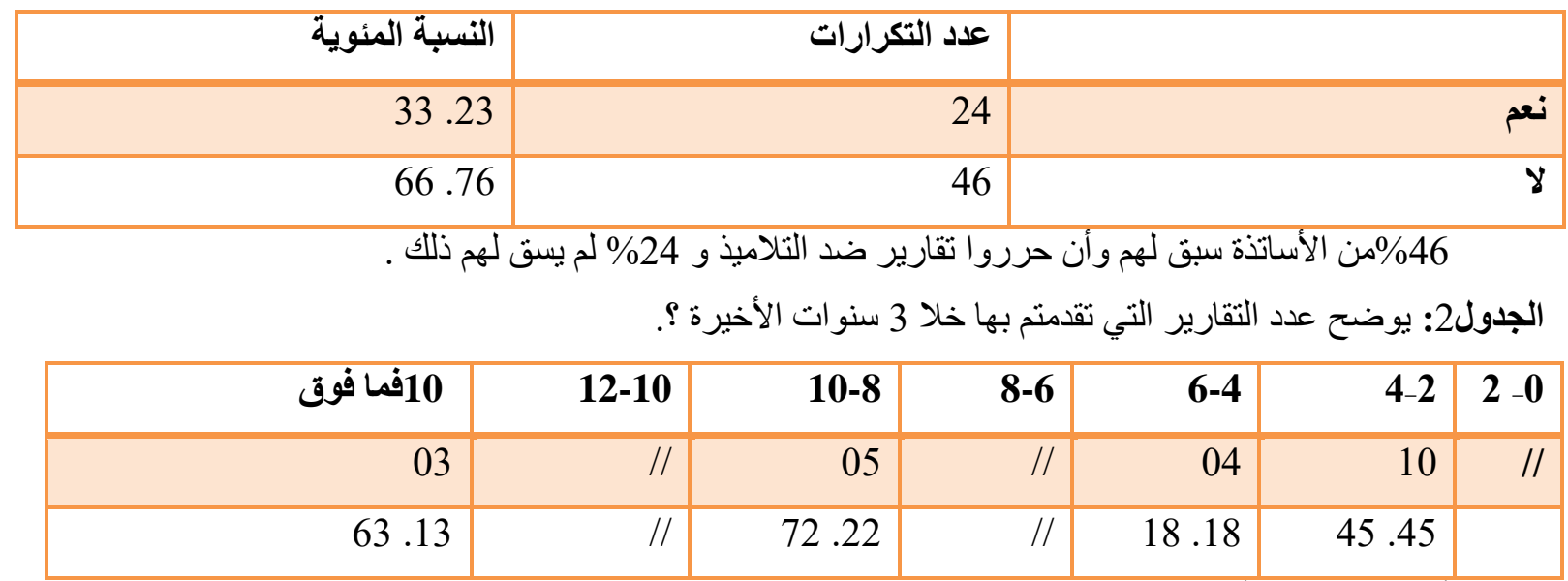

أكبر نسبة من الأساتذة حرروا مابين 2-4 تقرير وذللك بنسبة 45. 45\% و 22. 72 \% حر حروا من 8-10 تقارير

الجدول3: هل ترون أن مجلس التأديب هو وسيلة علاجية مناسبة للتخفيف من ظاهرة العنف في الوسط المدرسي؟

\begin{tabular}{|c|c|c|}
\hline النسبة المئوية & عدد التكرارات & \\
\hline 66.76 & 46 & نعم \\
\hline 33.23 & 14 & $\gamma$ \\
\hline
\end{tabular}

66 \% \% من الأساتذة يرون أن مجالس التاديب هي وسيلة علاجية مناسبة للتخفيف من ظاهرة العنف في الوسط

المدرسي.

الجدول 4 ماهي الاستر اتيجيات التي نرونها مناسبة للتخفيف من ظاهرة العنف في الوسط المدرسي ؟.

\begin{tabular}{|c|c|c|}
\hline$\%$ & نعم & 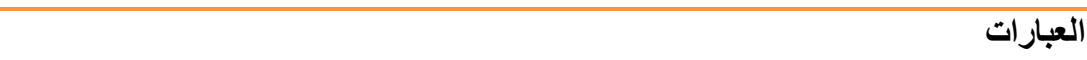 \\
\hline 33.48 & 29 & إحالة التلاميذ على مجالس تأديب . \\
\hline 45 & 27 & توسيع نطاق الاستعانة بوسائل الإعلام المسموعة المرئية، المكتوبة للتخفيف من الظاهرة \\
\hline 33.53 & 23 & إحالة التلميذ الذي يظهر هذا السلوك على مختص نفساني. \\
\hline 33.53 & 23 & تنظيم حملات تحسيسية داخل المؤسسات التربوية \\
\hline 33.28 & 17 & إعادة النظر في القوانين الرادعة لمثل هذه السلوكات في مضمون التشريع المدرسي \\
\hline 33.33 & 20 & تحرير تقارير ضد التلاميذ الذين يقومون بمثل هذا السلوك. \\
\hline 15 & 09 & اعتماد دورات تدريبية ذات مستوى عالمي لأعضاء الفريق الإداري والتربوي \\
\hline 66.26 & 16 & دمجج موضوع العنف، أخطاره، أسبابه واستر اتيجيات الوقاية ضمن المقررات الدراسي \\
\hline
\end{tabular}

نستخلص من خلال الجدول أن نسبة كبيرة من الأساتذة قدرت:ب 53. 33\% يرون أنه من الضروري إحالة التلميذ

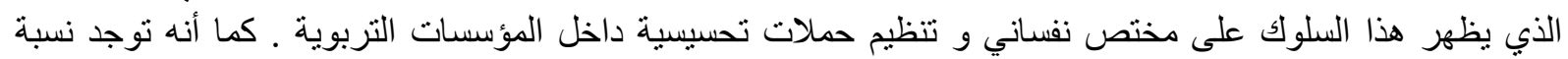
معتبرة قدرت ب: 48. 33\%من الأساتذة المستجوبين يرون أن احالة التلاميذ على مجالس التأديب من الأساليب المناسبة

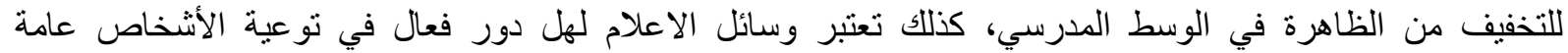

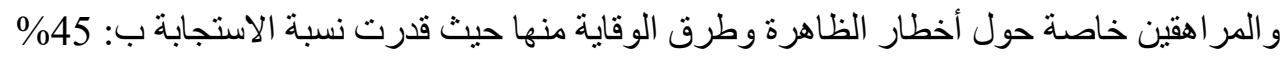




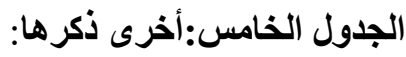

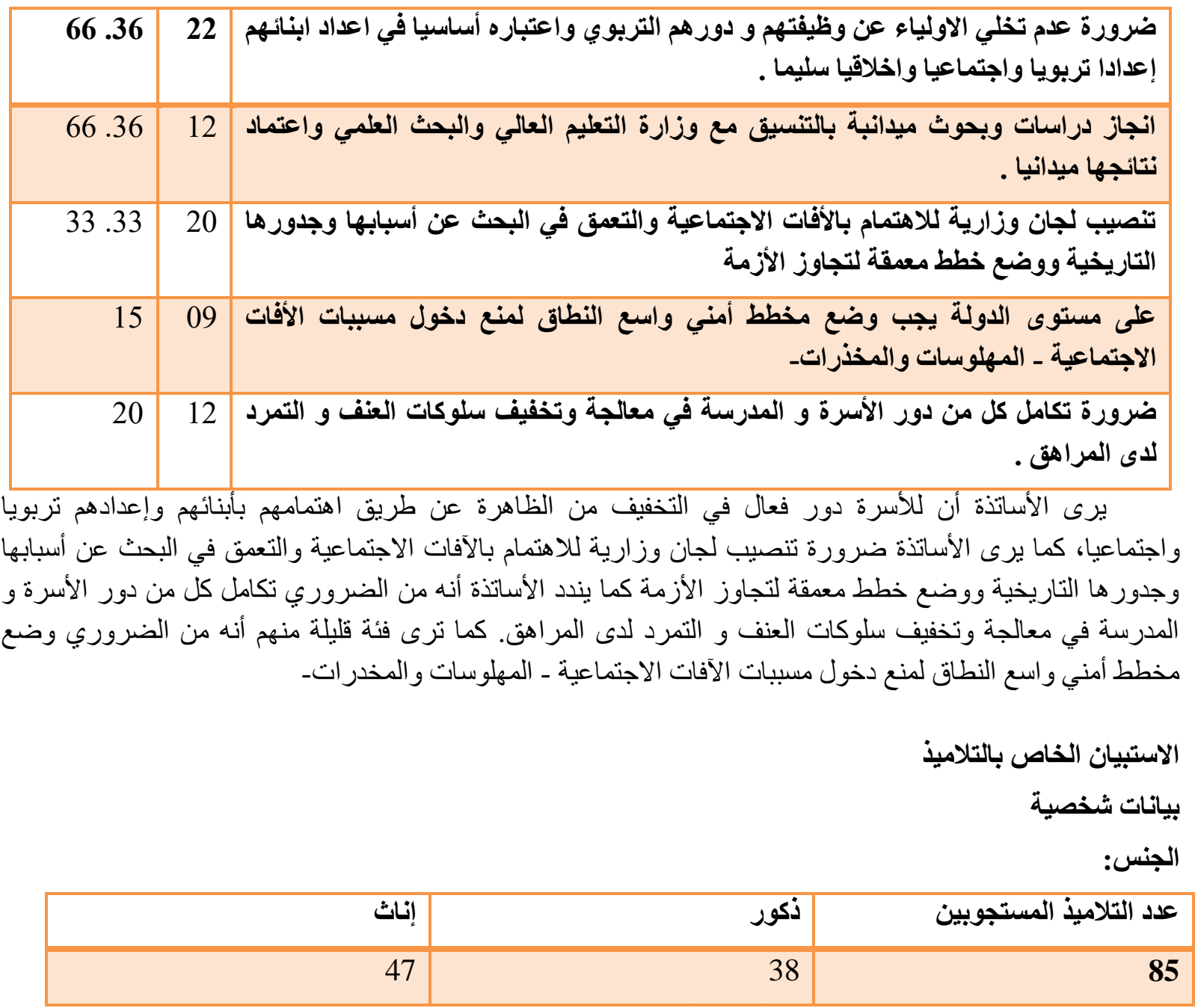

المصدر:من إنجاز الباحثة على ضوء نتائج الدراسة الميدانية

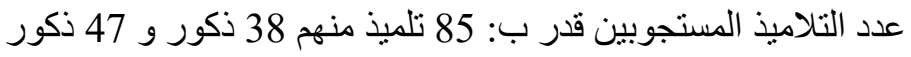

المستوى الاراسي: - المئ

\begin{tabular}{|c|c|c|c|c|c|}
\hline \multicolumn{2}{|c|}{ السنة3ثا } & \multicolumn{2}{|c|}{ السنة2ثا } & \multicolumn{2}{|c|}{ السنـة1ثا } \\
\hline$\%$ & العدد & $\%$ & العدد & $\%$ & العدد \\
\hline 29.15 & 13 & 17.61 & 52 & 52.23 & 20 \\
\hline
\end{tabular}

المصدر:من إنجاز الباحثة على ضوء نتائج الاراسة الميدانية

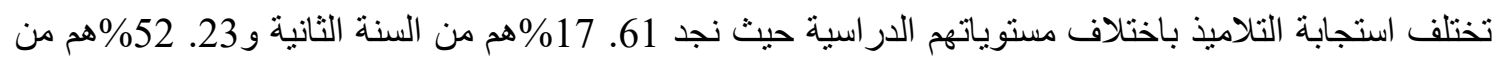

السنة الأولى 15. 29\% هم من السنة الثالثة

المحور الأول: واقع العنف في الوسط المدرسي و أنو اعه.

الجدول الأول: يوضح في أي مكان تشعر بالارتياح أكثر

\begin{tabular}{|c|c|c|c|c|c|}
\hline \multicolumn{2}{|c|}{ في المدرسة } & \multicolumn{2}{|c|}{ في الشارع } & \multicolumn{2}{|c|}{ في البيت } \\
\hline النسبة & التكر ار & النسبة & التكر ار & النسبة & التكرار \\
\hline 05.27 & 23 & 41.9 & 08 & 35.62 & 53 \\
\hline
\end{tabular}




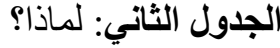

\begin{tabular}{|c|c|c|}
\hline$\%$ & التكرارث & 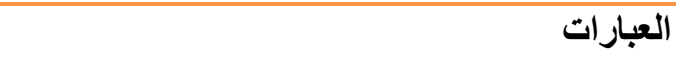 \\
\hline 82.38 & 33 & الحصول على الراحة النفسية والطمأنينة في البيت \\
\hline
\end{tabular}

حسبهم السبب هو الثعور بالطمأنينة والأمان. وبالتالي نستنتج أنه كلما أحس المر اهث بالطمأنسأنينة والأمن تخلى عن

سلوك العنف.

الجدول الثالث: يوضح هل من الضروري مكافحة كل سلوك يتسبب في تخريب المدرسة حسب التلاميذ؟

\begin{tabular}{|c|c|c|}
\hline النسبة المئوية & عدد التكرارات & \\
\hline 94.72 & 62 & نعم \\
\hline 48.29 & 23 & $\gamma$ \\
\hline
\end{tabular}

المصدر: من إنجاز الباحثة على ضوء نتائج الاراسة الميدانية

72. 94\% من التناميذ يرون أنه من الضروري مكافحة أي سلوك يتسبب في العنف في الوسط المدرسي

وبالتالي نستتنج أن المر اهقين يميلون الى الاحساس بضرورة توفر الأمن في الوسط المدرسي.

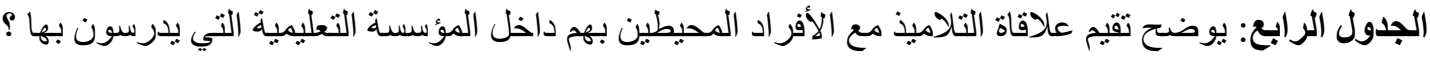

\begin{tabular}{|c|c|c|c|c|c|c|}
\hline \multicolumn{2}{|c|}{ علاقة مشحونة } & \multicolumn{2}{|c|}{ علاقة هادئة } & \multicolumn{2}{|c|}{ علاقة جيدة } & \\
\hline$\%$ & العدد & $\%$ & العدد & $\%$ & العدد & \\
\hline 16.47 & 14 & 52.43 & 37 & 11.14 & 12 & المدير \\
\hline 29.41 & 25 & 24.70 & 21 & 76.11 & 10 & الناظر \\
\hline 17.64 & 15 & 27.05 & 23 & 52.23 & 20 & المراقب العام \\
\hline 20 & 17 & 27.05 & 23 & 47.16 & 14 & التربوي \\
\hline 24.70 & 21 & 35.29 & 30 & 37,64 & 32 & الأستاذ \\
\hline 10.58 & 09 & 10.58 & 09 & 70.44 & 38 & الزملاء \\
\hline 9.41 & 08 & 30.58 & 26 & 52.23 & 20 & العمال المهنيين \\
\hline 24.70 & 21 & 30.58 & 26 & 29.15 & 13 & الإداريين \\
\hline
\end{tabular}

المصدر: من إنجاز الباحثة على ضوء نتائج الدراسة الميدانية

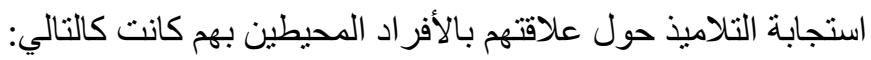

41 29. من التلاميذ يؤكدون أن لهم علاقة مشحونة مع ناظر المؤسسة، بينما 24. 70\% منهم لهم علاقة مشحونة مع الأستاذ و الإداريين.

64 \%37. لهم علاقة جيدة مع الأساتذة. معنى ذلك أن أفعال المر اهقين داخل الوسط المدرسي هي سلوكات انفعالية

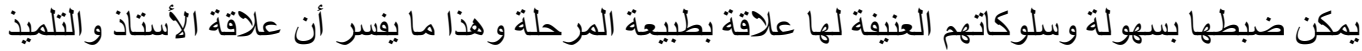
هي علاقة يمكن احتو ائها من طرف الأستاذ اذا تعامل مع الموقف بحكمة . 
الجدول الخامس: يوضح هل تعرض التلميذ لسلوك عدواني من طرف زملائه أو أحد أعضاء الفريق الإداري أو التربوي

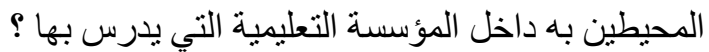

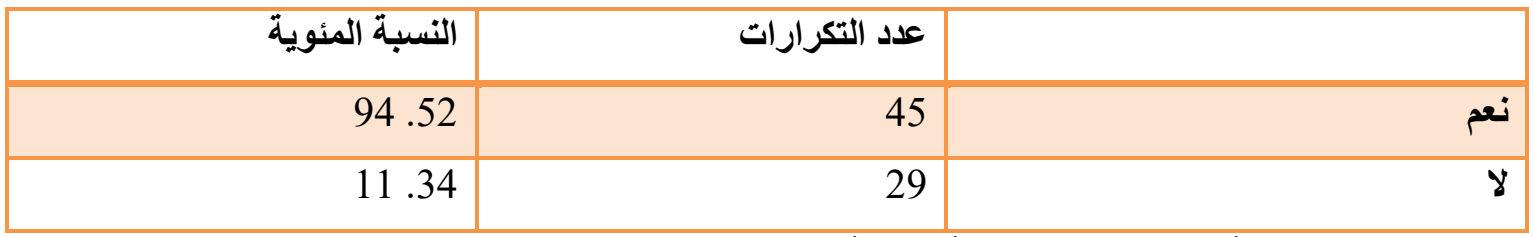

المصدر:من إنجاز الباحثة على ضوء نتائج الاراسة الميدانية 52. 94 \% من التلاميذ يرون أنهم سبق لهم و أن و اجهو ا سلوك عنيف من طرف الحيدة احد افر اد الفريق الإداري أو التربوب . الجدول الساد:من هؤو لاء الأشخاص وماهو نوع هذا العنف ؟

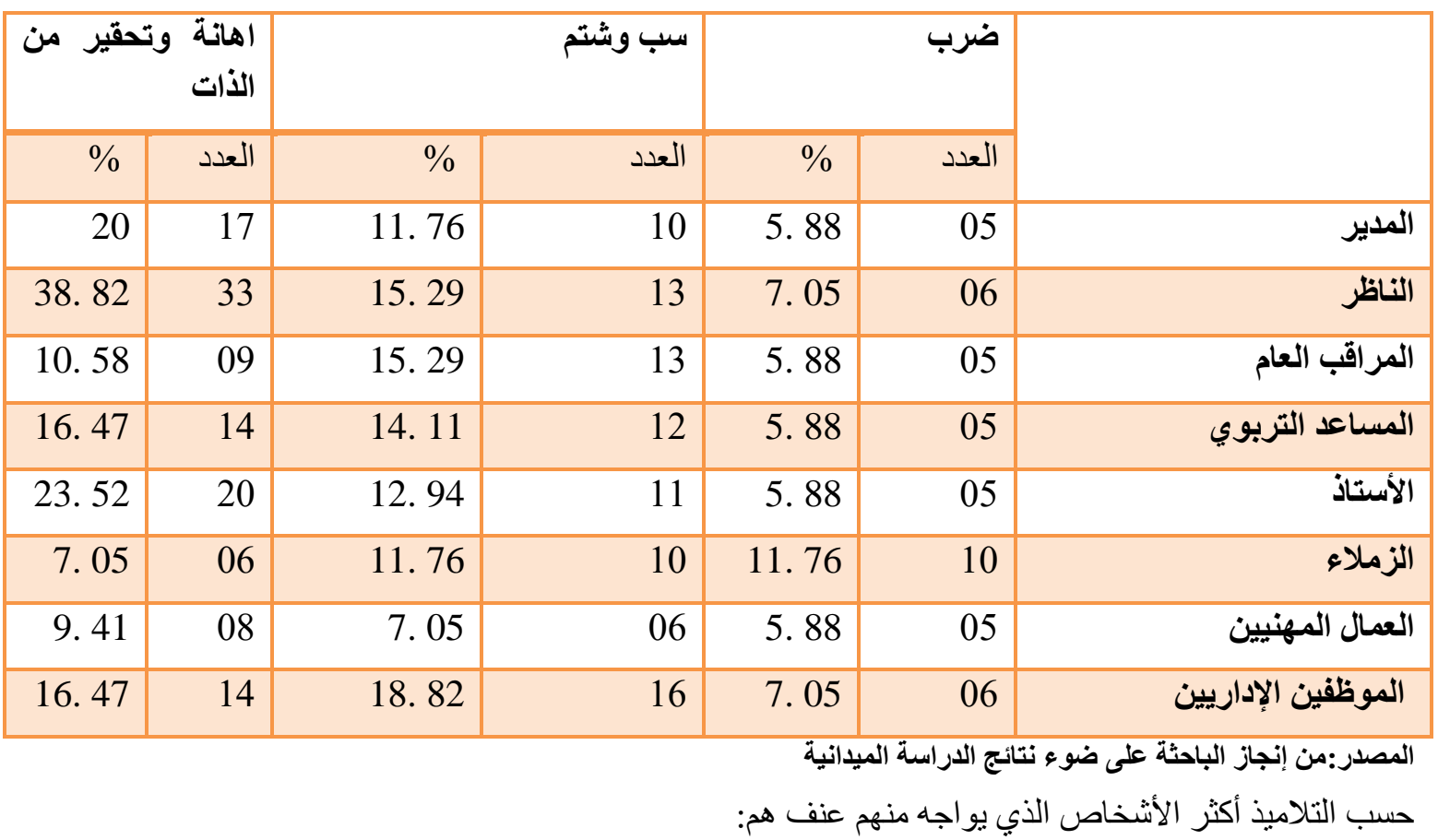

ناظر الثانوية عن طريث استعمال أساليب الاهانة والتحقبر من الذات حيث كانت الاستجابة حول هذه العبارة 38.

23. 52\% برون أن الأستاذ يقوم بممارسة العنف اللفظي على التلميذ ـ 20\% يرون أ، المدير أيضا يقوم باهانة

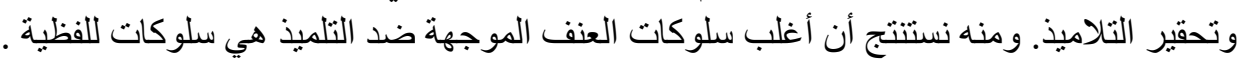

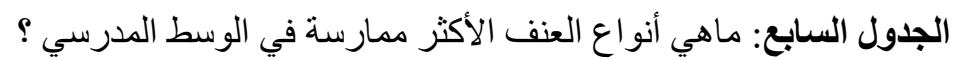

\begin{tabular}{|c|c|c|c|c|c|}
\hline مخامة & في المؤسسة عمدات & سرقة منتلكات & اعتاء جسدي & (عتداء لفظي & السلوك \\
\hline 16 & 47 & 30 & 28 & 52 & ها النوع \\
\hline 82.18 & 29.55 & 29.35 & 94.32 & 17.61 & \\
\hline
\end{tabular}

السلوكات العدو انية الأكثر انتشار ا في الوسط المدرسي هي الاعتداء اللفظي وتخريب ممتلكات المؤسسة عمدا حيث تر اوحت النسب ما بين 55. 29\%و و 61. 17\% بالنسبة لبقية الاستجابات هي متفاوتة. 
المحور الثاني أسباب تفشى ظاهرة العنف في الوسط المدرسي وإستراتيجية الوقاية منه:

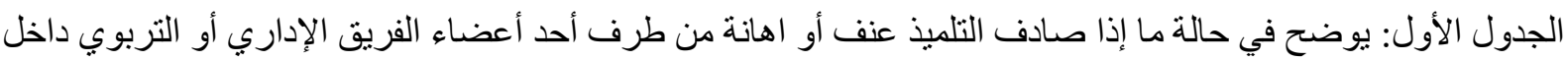

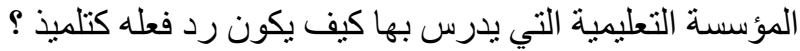

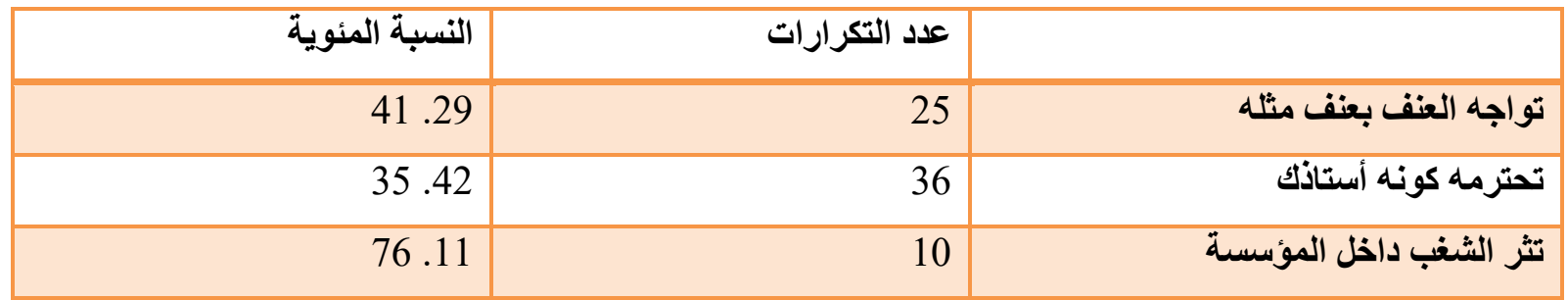

نستخلص من الجدول أن ردود أفعال التلاميذ ضد الأساتذة ة حسب استجاباتهم تكون باحتر ام الأستاذ كونه مربي

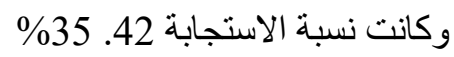

ونسبة قليلة منهم يرون أنه يجب مقابلة العنف بالعنف أو اثارة الثغب حيث قدرت ب: 29. 41\% \% 11. 76\%

الجدول الثاني: يوضح الأسباب التي تدفع بالمر اهق إلى اقتراف العنف داخل المؤسسة ؟ بأبها

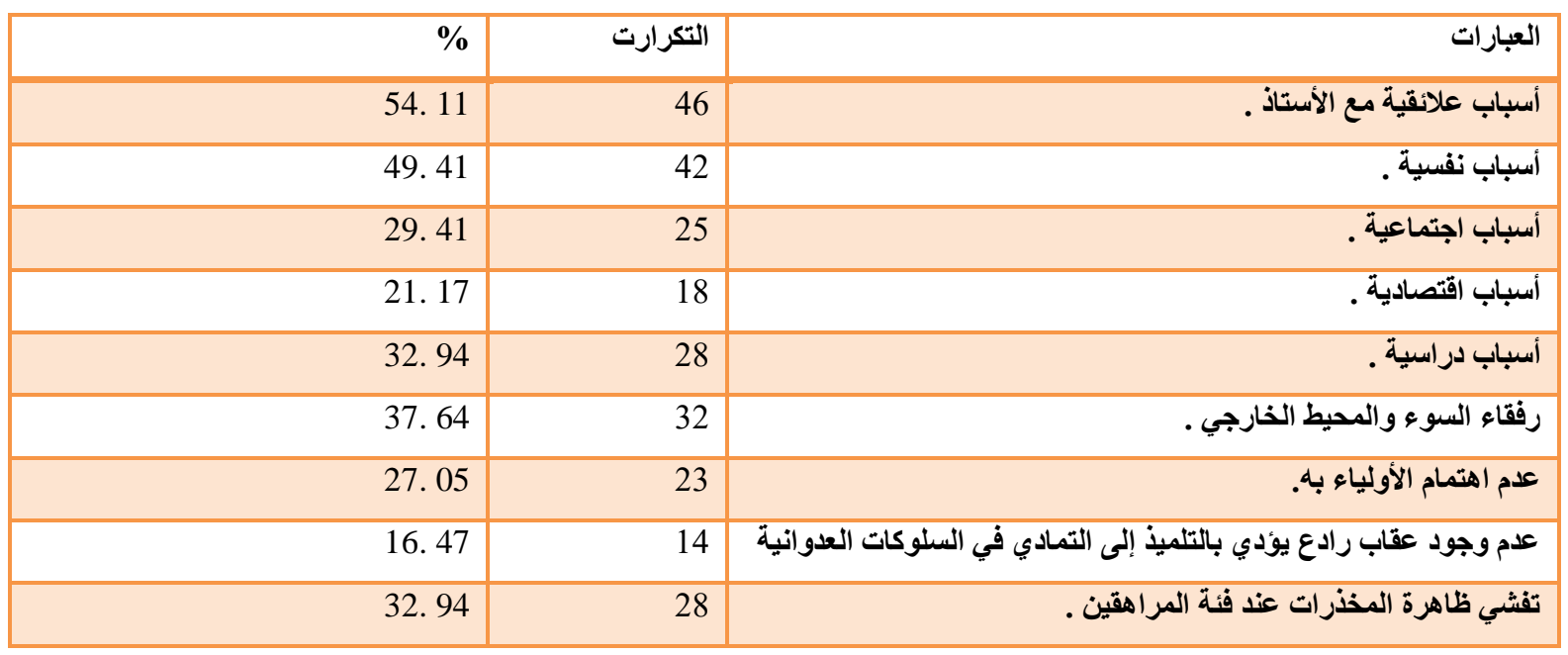

54. 11\% من التلاميذ برجعون الأسباب التي تدفع المراهق الى اقتراف العنف في الوسط المدرسي هي أسباب

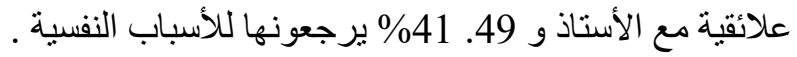

بينما 37. 64 \% يرجعونها الى الاحتكالك برفقاء السوء و 32. 94 \% يسندونها الى الأسباب الدر اسية .

الجدول الثالث: يوضح أكثر السلوكات التي تجعل التلاميذ يثيرون الثنب أو يقترفون سلوكات عنيفة داخل المؤسسة التعليمية ؟

\begin{tabular}{|c|c|c|}
\hline$\%$ & العدد & 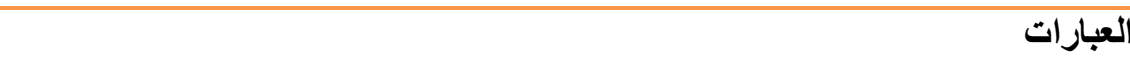 \\
\hline 82.58 & 50 & التهميش والحقرة من طرف الأستاذ أو الإدارة . \\
\hline 82.38 & 33 & حصول التلميذ على نقاط لا تعكس مجهوده الدر اسي أثناء الامتحان. \\
\hline 52.43 & 37 & إذا تجاوز الأستاذ أو أحد أعضاء الفريق الإداري و التربوي حدوده مع التلميذ \\
\hline 58.30 & 26 & في حالة ما إذا كان التلميذ في حالة مز اجية سيئة . \\
\hline 64.37 & 32 & أثناء استخدام الأستاذ أسلوب عقابي مهين يثير سخط التلميذ . \\
\hline 35.42 & 36 & اذا وجد التلميذ أن الأستاذ غير كفئ في عمله و لا يستطيع التحكم في القسم . \\
\hline 35.22 & 19 & اذا وصلت الى المؤسسة التعليمية ومنعت من الدخول بعد غيابك عن الدر اسة لمدة معينة . \\
\hline
\end{tabular}




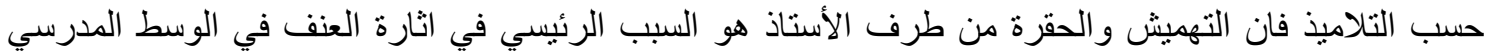

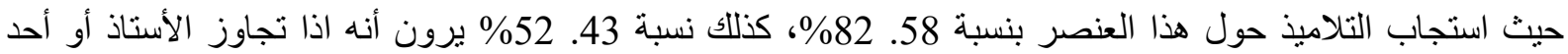

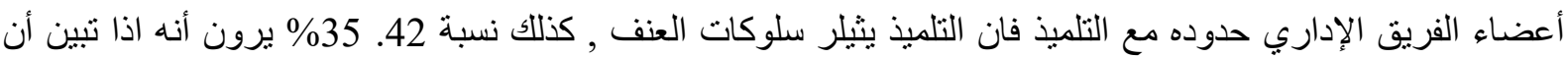
الأستاذ غير كفئ في مادته فانه يجعل التلاميذ يثيرون الثنغب في الحصة . الجدول الرابع: يوضح ماهي الحلول التي يقترحها التلميذ للحد من ظاهرة العنف في الوسط المدرسي ؟

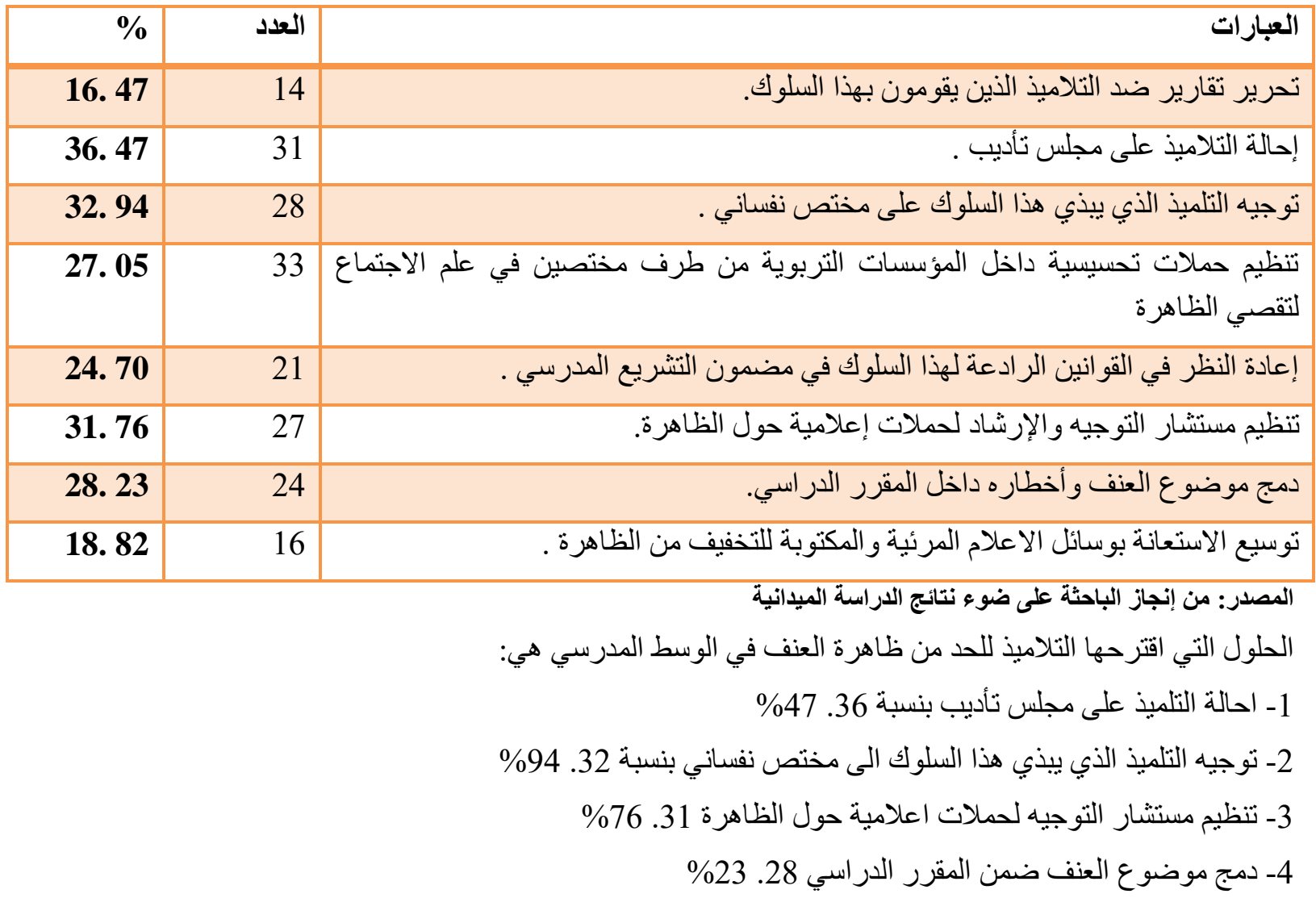

النتائج العامة:

النتائج المستخلصة بالنسبة لأعضاء الفريق الإداري :

1- ضرورة استعمال أسلوب التأديب بتحرير تقارير ضد هؤلاء التلاميذ بنسبة 72. 22\%

2- احالة هؤ لاء التلاميذ على مجلس تأديب 85. 55\%

3- نوسيع نطاق الاستعانة بوسائل الاعلام المسموعة، المرئية، المكتوبة للتخفيف من الظاهرة 96. 66\%

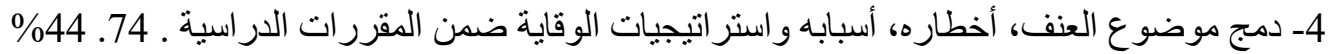

5- اعادة النظر في القوانين الر ادعة لمثل هذه السلوكات في مضمون التشريع المدرسي. 48. 88\%

6- توسيع نطاق تكوين المختص النفساني ومستشار التوجيه في مجال در اسة الظو اهر الاجتماعية وتحسين أساليب الاتصال

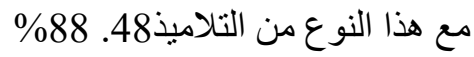
7- احالة التلميذ الذي يظهر هذا السلوك على مختى 8- تطبيق تقنيات الوساطة في الوسط المدرسي24. 44 4

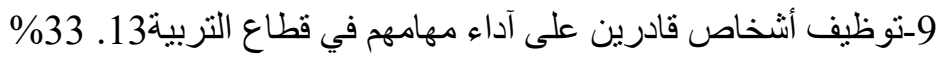


10- ضرورة عدم تخلي الاولياء عن وظيفتهم و دور هم التربوي و اعتباره أساسيا في اعداد ابنائهم إعدادا تربويا واجتماعيا

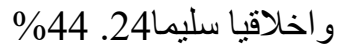
11- تعزيز المنظومة القيمية للمر اهقين من اجل مو اجهة التغير ألقيمي وحمايتهم من الصر اع الذي يقودهم إلى انتهاج سبل

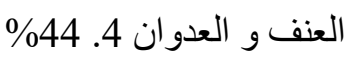
12 تفعيل اليات الضبط و الردع داخل المؤسسات التعليمية بشرط ان تحمل معاني التهذيب و التعديل لا معاني العقاب و

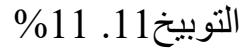

13 ـ تكوين افر اد الجماعة التربوية وتو عيتهم بأهمية دور هم في تنشئة أجيال منو افقة نفسيا واجتماعياو علميا5. 55\% 14- ضرورة تكامل كل من دور الأسرة و المدرسة في معالجة وتخفيف سلوكات العنف و التمرد لدى المر اهق13. 33\%

النتائج المستخلصة بالنسبة للأساتذة:

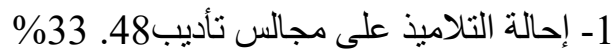
2-توسيع نطاق الاستعانة بوسائل الإعلام المسموعة، المرئية، المكتوبة للتخفيف من الظاهرة45\% 3-نتظيم حملات تحسيسية داخل المؤسسات التربوية53. 33\%

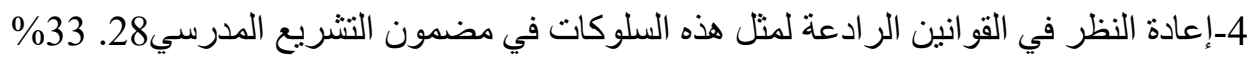
5-تحرير تقارير ضد التلاميذ الذين يقومون بمثل هذا السلوك33. 33. 33.

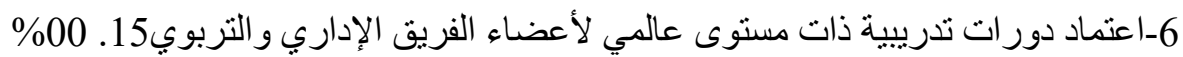

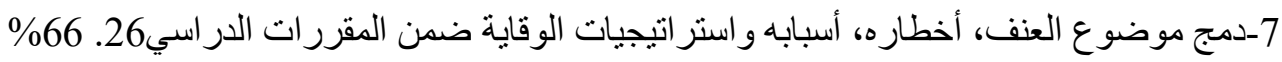
8-ضرورة عدم تخلي الاولياء عن وظيفتهم و دور هم التربوي و اعتباره أساسيا في اعداد ابنائهم إعدادا تربويا واجتماعيا

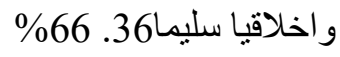

9ـانجاز در اسات وبحوث ميدانبة بالتنسيق مع وز ارة التعليم العالي و البحث العلمي و اعتماد نتائجها ميدانبا36. 66\%

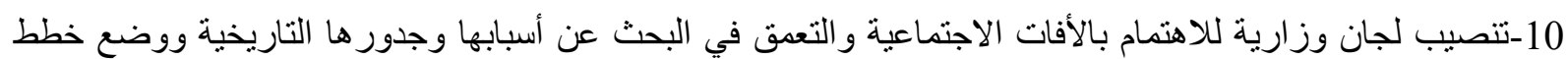
معقة لتجاوز الأزمة33. 333 11-على مستوى الدولة يجب وضع مخطط أمني واسع النطاق لمنع دخول مسببات الأفات الاجتماعية ـ المهوسات

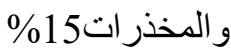
12-ضرورة تكامل كل من دور الأسرة و المدرسة في معالجة وتخفيف سلوكات العنف و التمرد لدى المر اهق ـ 20\% النتائج المستخلصة من استجواب التلاميذ : 1- تحرير تقارير ضد التلاميذ الذين يقومون بهذا السلوك. 16. 47\%

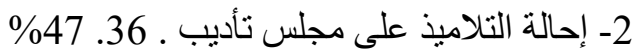
3- نوجيه التلميذ الذي يبذي هذا السلوك على مختص نفساني ـ 32. 94\% 4ـ تتظبم حملات تحسيسية داخل المؤسسات التربوية من طرف مختصين في علم الاجتماع لتقصي الظاهرة27. 05\% 5- إعادة النظر في القو انين الر ادعة لهذا السلوك في مضمون التشريع المدرسي ـ 24. 70\% 6- تنظيم مستشار التوجيه والإرشاد لحملات إعلامية حول الظاهرة. 31. 76\% 7- دمج موضوع العنف وأخطاره داخل المقرر الدر اسي. 28. 23 0.

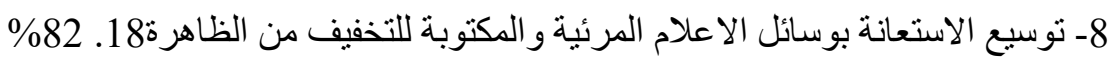


توصلنا من خلال دراستنا للعنف في الوسط المدرسي لاى فئة التلاميذ الأساتذة والهيئة الإدارية الى عدة حلول

بيداغوجية محضة لظاهرة العنف في الوسط المدرسي نضف اليها حسب وجهتنا التربوية الخاصة كميدانيين مايلي: -1 - تفعيل دور جمعية أولياء التلاميذ بالاتصال وتحسيس الأولياء بضرورة التكفل التربوبي والاجتماعي بالتنلاميذ.

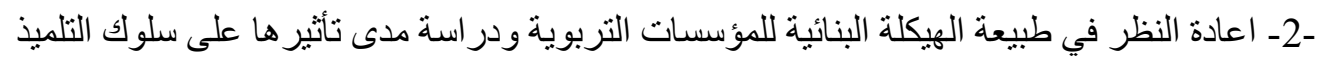
-3- تفعيل و تيرة النشاطات اللاصفية و إثر ائها -4- نبذ سلوك العنف من طرف أعضاء الفريق الإداري و التربوي

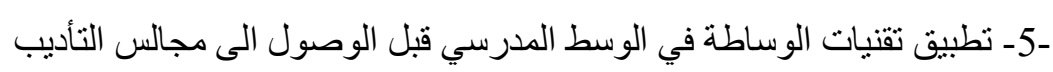
-6-وضع إستر اتيجية محكمة ضمن مشروع تربوي مسطر - مشروع المؤسسة مثلا- لمر افقة التلميذ خلال مر احل حياته

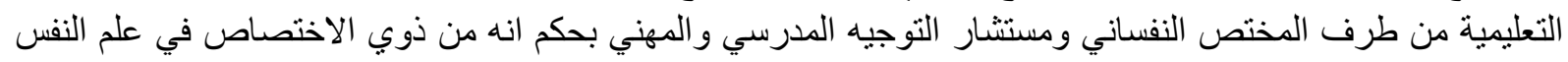

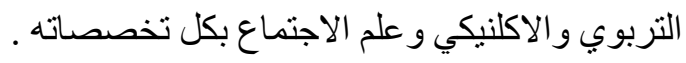

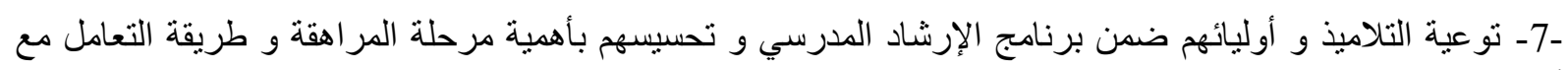
أبنائهم في هذه المرحلة الحساسة .

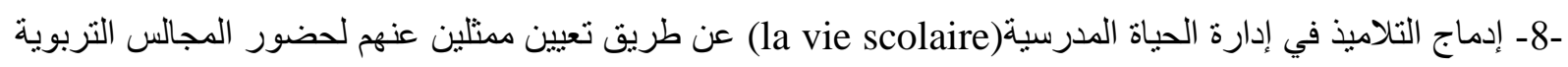

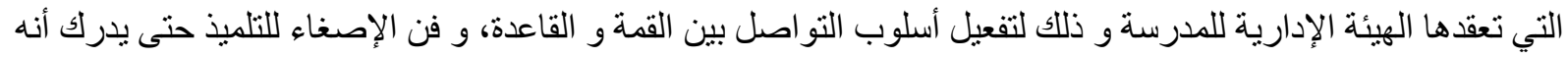

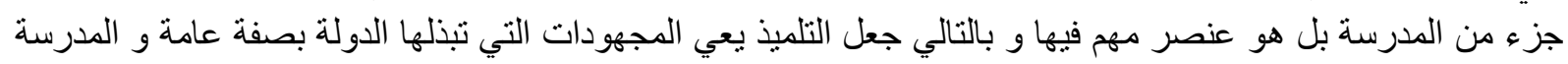

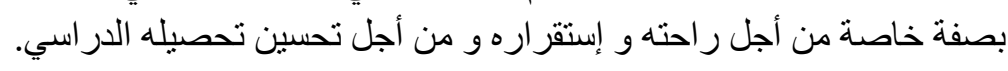

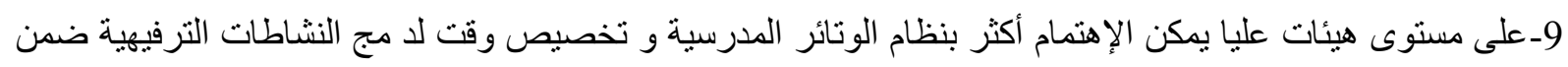

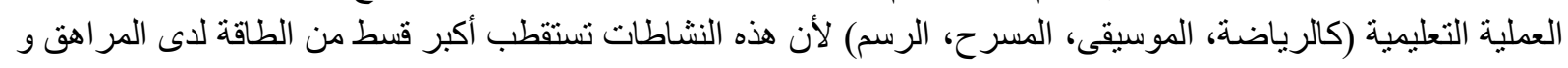

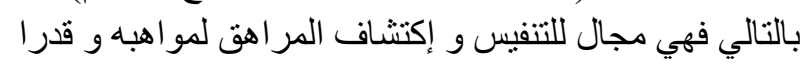
-10-الإهتمام بالمر اهق و الإصغاء الجيد إليه من خلال فريق الطب النفسي (المختصين النفسانيين و مستشاري التوجيه. )

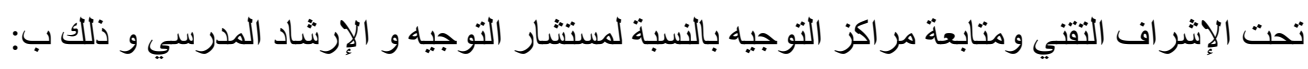

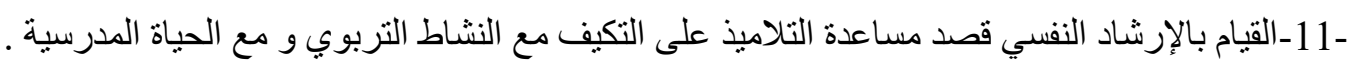
-12-إجر اء الفحوص النفسية الضرورية (في إطار التخصص الإكلينيكي قصد التكفل بالتلاميذ الذين يعانون من مشاكل خاصة . -13-المساهمة في عملية إستكثاف التلاميذ المتخلفين مدرسيا و المشاركة في تنظيم التعليم المكيف و دروس الدعم و

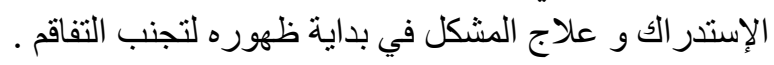

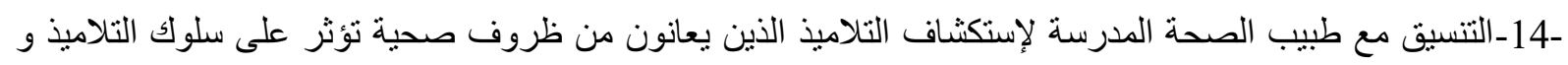

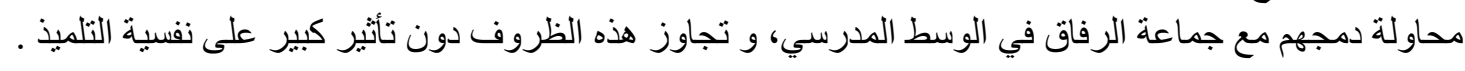

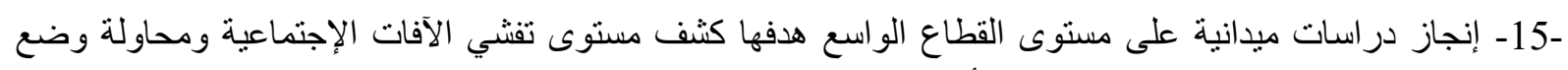
إستر اتيجيات تدخل آنية مع عدة شركاء للتحكم أكثر في الظاهرة. 
نتائج الدر اسة الميدانية بو لاتي فسنطينة وسطيف سجل مجالس التأديب بمديرية التربية

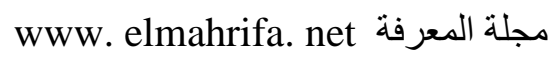

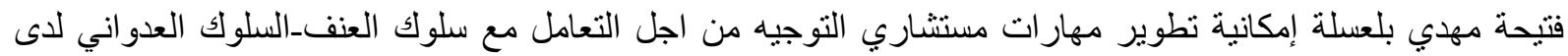

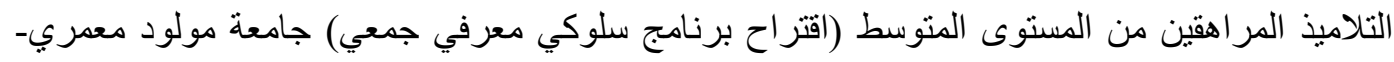

$$
\text { تيزي وزو. }
$$

